\title{
Positron emission tomography neuroimaging in neurodegenerative diseases: Alzheimer's disease, Parkinson's disease, and amyotrophic lateral sclerosis
}

\author{
Krzysztof Barc ${ }^{1}$, Magdalena Kuźma-Kozakiewicz ${ }^{1,2,3}$ \\ ${ }^{1}$ Department of Neurology, University Clinical Centre of Medical University of Warsaw, Warsaw, Poland \\ ${ }^{2}$ Department of Neurology, Medical University of Warsaw, Warsaw, Poland \\ ${ }^{3}$ Neurodegenerative Disease Research Group, Medical University of Warsaw, Warsaw, Poland
}

\begin{abstract}
Neurodegenerative diseases are a growing problem of ageing societies. Their insidious onset, and the lack of reliable biomarkers, result in significant diagnosis delays. This article summarises the results of studies on the use of positron emission tomography (PET) in the diagnosis of Alzheimer's disease, Parkinson's disease, and amyotrophic lateral sclerosis. It focuses on clinical-pathogenetic aspects of individual diseases, as well as disease-specific patterns relevant in differential diagnosis and in assessing the risk of disease development and prognosis.
\end{abstract}

Key words: Alzheimer's disease, Parkinson's disease, amyotrophic lateral sclerosis, positron emission tomography (Neurol Neurochir Pol 2019; 53 (2): 99-112)

\section{Introduction}

Positron emission tomography (PET) is a nuclear functional imaging technique that enables an assessment of physiological parameters, such as metabolic rate, receptor density or protein deposition. The images are obtained with scanners detecting radioactive ligands usually administered intravenously (Tab. 1). Radiotracers used in PET imaging are mainly labelled with carbon-11 or fluorine-18. Carbon-11 labelled radiotracers have a short half-life time of 20 minutes, which requires a cyclotron on-site and restricts their use only to highly specialised hospitals. With a half-life time of 110 minutes, fluorine-18 labelled radiotracers can be manufactured off-site and transferred to the place of administration [1]. Although considerable information can be acquired from the PET functional image (especially if the functional signal is preserved), a detailed anatomical analysis may require normalisation by image fusion of PET and computed tomography (CT) or magnetic resonance imaging (MRI) [2].

\section{Alzheimer's disease}

Alzheimer's disease (AD) is a chronic neurodegenerative disease with an accumulation of amyloid- $\beta(A \beta)$ and hyperphosphorylated tau proteins resulting in the formation of amyloid plaques (AP) and neurofibrillary tangles (NFTs). It is characterised by a progressive decline in memory functions, deterioration of other cognitive abilities (language functions, visuospatial abilities, complex tasks involving planning/handling), as well as changes in behaviour and personality. In 2015 dementia was estimated to affect 46.8 million people worldwide, with AD being its most common cause. This number is expected to double every 20 years [3].

\section{$\mathrm{PET}$ in diagnosis of $\mathrm{AD}$}

The majority of PET studies in AD are performed with two groups of radioligands: biomarkers of neuronal dysfunction, and biomarkers of $A \beta$ and tau protein depositions.

Address for correspondence: Magdalena Kuźma-Kozakiewicz, Department of Neurology, University Clinical Centre of Medical University of Warsaw, Warsaw, Poland, e-mail: mkuzma@wum.edu.pl 
Table 1. PET radioligands used in diagnostics of neurodegenerative diseases

\begin{tabular}{|c|c|c|}
\hline $\begin{array}{l}\text { PET radioligand (short } \\
\text { names) }\end{array}$ & Target & Clinical utility \\
\hline${ }^{18} \mathrm{~F}-\mathrm{FDDNP}$ & $\begin{array}{l}\text { amyloid- } \beta(A \beta) \text { and tau-protein } \\
\text { assessing } A \beta \text { and tau-protein } \\
\text { depositions }\end{array}$ & $\begin{array}{l}\text { diagnosis and evaluation of } A D\left({ }^{18} F-F D D N P\right) ; \\
\text { differentiating between PSP and PD }\left({ }^{18} F-F D D N P\right)\end{array}$ \\
\hline $\begin{array}{l}{ }^{18} F-A V-1451(T 807), \\
{ }^{18} F-T 808, \\
{ }^{18} F-T H K-5105, \\
{ }^{18} F-T H K-5117, \\
{ }^{18} F-T H K-5351, \\
{ }^{11} C-P B B 3\end{array}$ & $\begin{array}{l}\text { tau-protein } \\
\text { assessing tau-protein deposi- } \\
\text { tions }\end{array}$ & $\begin{array}{l}\text { diagnosis of } A D\left({ }^{18} F-T H K-5351,{ }^{11} C-P B B 3\right) ; \\
\text { evaluation of } A D\left({ }^{18} F-A V-1451,{ }^{11} C-P B B 3\right) ; \\
\text { differentiating between } A D \text { and } C N / M C I\left({ }^{18} F-T H K-5351,{ }^{11} C-P B B 3\right)\end{array}$ \\
\hline $\begin{array}{l}{ }^{11} \mathrm{C}-\mathrm{PiB}, \\
\text { florbetapir, } \\
\text { florbetaben, } \\
\text { flutemetamol, } \\
{ }^{3} \mathrm{H}-\mathrm{BF}-227, \\
{ }^{18} \mathrm{~F}-\mathrm{AZD} 4694\left({ }^{18} \mathrm{~F}-\right. \\
\mathrm{NAV} 4694)\end{array}$ & $\begin{array}{l}\text { amyloid- } \beta(A \beta) \\
\text { assessing } A \beta \text { depositions }\end{array}$ & $\begin{array}{l}\text { diagnosis of } A D\left({ }^{11} C-P i B, \text { florbetapir, florbetaben, flutemetamol); }\right. \\
\text { differentiating between } A D \text { and } C N / M C I \text { or FTD ("1"C-PiB, florbetapir); } \\
\text { predicting the MCI-AD conversion (" }\left({ }^{11}-P i B\right)\end{array}$ \\
\hline${ }^{11} C-M P 4 A$ & $\begin{array}{l}\text { acetylcholinesterase enzyme } \\
\text { assessing the brain acetylcholin- } \\
\text { esterase activity }\end{array}$ & $\begin{array}{l}\text { diagnosis of } A D\left({ }^{11} C-M P 4 A\right) \text {; } \\
\text { differentiating between } A D \text { and } D L B\left({ }^{11} C-M P 4 A\right)\end{array}$ \\
\hline $\begin{array}{l}{ }^{18} F-D O P A, \\
{ }^{18} F-F M T\end{array}$ & $\begin{array}{l}\text { amino acid decarboxylase } \\
\text { assessing striatal dopaminergic } \\
\text { presynaptic function }\end{array}$ & $\begin{array}{l}\text { diagnosis and evaluation of PD }\left({ }^{18} \mathrm{~F}-D O P A,{ }^{18} \mathrm{~F}-F M T\right) \\
\text { differentiating between PD and APS }\left({ }^{18} \mathrm{~F}-\mathrm{DOPA}\right)\end{array}$ \\
\hline $\begin{array}{l}{ }^{11} \mathrm{C}-\mathrm{C} F \mathrm{~T}, \\
{ }^{18} \mathrm{~F}-\text { beta-CFT, } \\
{ }^{11} \mathrm{C}-\mathrm{MP}, \\
{ }^{11} \mathrm{C}-\mathrm{FE}-\mathrm{CIT}, \\
{ }^{11} \mathrm{C}-\mathrm{PE} 2 \mathrm{I}, \\
{ }^{18} \mathrm{~F}-\mathrm{FP}-\mathrm{CIT}\end{array}$ & $\begin{array}{l}\text { dopamine transporter (DAT) } \\
\text { assessing DAT distribution }\end{array}$ & 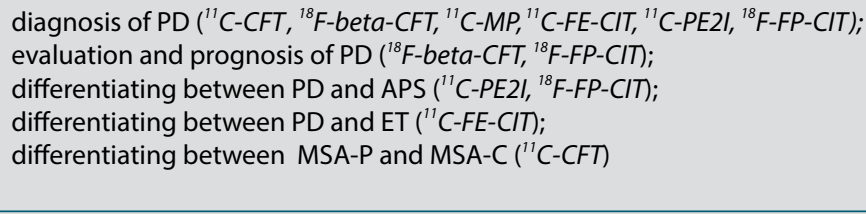 \\
\hline $\begin{array}{l}{ }^{11} C-D T B Z, \\
{ }^{18} F-A V-133 \text { (florbenazine) }\end{array}$ & $\begin{array}{l}\text { vesicular monoamine trans- } \\
\text { porter } 2 \text { (VMAT2) } \\
\text { assessing VMAT2 distribution }\end{array}$ & $\begin{array}{l}\text { diagnosis of PD }\left({ }^{11} C-D T B Z,{ }^{18} F-A V-133\right) ; \\
\text { differentiating between DLB and AD }\left({ }^{18} F-A V-133\right) ; \\
\text { evaluation of cognitive performance in DLB }\left({ }^{18} F-A V-133\right) \text {; } \\
\text { evaluation of motor performance in PD }\left({ }^{11} C-D T B Z\right)\end{array}$ \\
\hline $\begin{array}{l}{ }^{11} \mathrm{C} \text {-raclopride, } \\
{ }^{11} \mathrm{C}-\mathrm{n} \text {-methylspiperone, } \\
{ }^{11} \mathrm{C}-\mathrm{FLB} \text { 457, } \\
{ }^{18} \mathrm{~F} \text {-fallypride, } \\
{ }^{18} \text {-desmethoxyfallypride }\end{array}$ & $\begin{array}{l}\text { D2 receptor } \\
\text { assessing postsynaptic dopami- } \\
\text { nergic function }\end{array}$ & $\begin{array}{l}\text { diagnosis of PD }\left({ }^{11} \mathrm{C} \text {-raclopride, }{ }^{18} \mathrm{~F} \text {-fallypride); }\right. \\
\text { differentiating between PD and APS }\left({ }^{18} \mathrm{~F} \text {-desmethoxyfallypride); }\right. \\
\text { assessing the risk of developing "wearing-off" fluctuations }\left({ }^{11} \mathrm{C} \text {-raclopride }\right)\end{array}$ \\
\hline $\begin{array}{l}{ }^{11} C-(R)-P K 11195, \\
{ }^{11} C-P B R 28\end{array}$ & $\begin{array}{l}\text { translocator protein-18 kDa } \\
\text { (TSPO) } \\
\text { assessing microglia activation }\end{array}$ & $\begin{array}{l}\text { differentiating between PDD and non-demented PD (" } C-(R)-P K 11195) \text {; } \\
\left.\text { diagnosis of ALS ( }{ }^{11} C-(R)-P K 11195\right)\end{array}$ \\
\hline${ }^{11} \mathrm{C}$-flumazenil & $\begin{array}{l}\text { GABA-A } \\
\text { assessing GABA-ergic function }\end{array}$ & $\begin{array}{l}\text { diagnosis, evaluation and prognosis of ALS }\left({ }^{11} \mathrm{C} \text {-flumazenil); }\right. \\
\text { differentiating between ALS and PLS }\left({ }^{11} \mathrm{C} \text {-flumazenil) }\right.\end{array}$ \\
\hline${ }^{11} \mathrm{C}$-deprenyl-D2 & $\begin{array}{l}\text { MAO-B } \\
\text { assessing astrocytosis activation }\end{array}$ & diagnosis of ALS $\left({ }^{11} \mathrm{C}\right.$-deprenyl-D2) \\
\hline
\end{tabular}

PET — positron emission tomography; AD — Alzheimer's disease; PSP — progressive supranuclear palsy; PD — Parkinson's disease; $C N$ - cognitively normal; $M C l$ - mild cognitive impairment; FTD — frontotemporal dementia; DLB — dementia with Lewy bodies; ET —essential tremor; MSA-P — multiple systemic atrophy-parkinsonian; MSA-C — multiple systemic atrophy-cerebellar; PDD — Parkinson's disease dementia; APS — atypical parkinsonian syndromes; ALS — amyotrophic lateral sclerosis; PLS — primary lateral sclerosis

\section{${ }^{18}$ F-FDG}

Neuronal dysfunction is mainly evaluated with ${ }^{18} \mathrm{~F}$-fluorodeoxy-glucose $\left({ }^{18} \mathrm{~F}\right.$-FDG), a well-established biomarker of cerebral glucose metabolism. Glucose uptake in $\mathrm{AD}$ patients is characterised by hypometabolism in posterior cingulateprecuneas, posterior lateral and medial temporal-parietal association cortex and lateral frontal cortex [4-7] (Tab. 2). A more pronounced and extensive hypometabolism is present in earlyonset compared to late-onset $\mathrm{AD}$ [8]. Interestingly, reaching the same severity of clinical dementia requires a greater hypometabolism in early- as compared to late-onset disease [8]. Both the aphasic (aphasic AD) and the posterior cortical atrophy (PCA) variant of AD (visuospatial AD), present different glucose uptake patterns when compared to typical $\mathrm{AD}$ (memory AD). A marked lateralisation of the hypometabolism to the left hemisphere has been found in the aphasic form of $\mathrm{AD}$, while predominant posterior temporoparietal and occipital hypometabolism has been found in the visuospatial 
Table 2. Glucose uptake patterns in neurodegenerative disorders

\begin{tabular}{|c|c|c|c|c|c|c|c|c|c|c|c|c|c|}
\hline \multirow[t]{3}{*}{ Disorder } & \multicolumn{2}{|c|}{ Prevalent pattern } & \multicolumn{9}{|c|}{ Anatomical distribution of glucose uptake patterns } & \multirow{3}{*}{$\begin{array}{l}\text { Po- } \\
\text { ste- } \\
\text { rior } \\
\text { cin- } \\
\text { gula- } \\
\text { te }\end{array}$} & \multirow{3}{*}{$\begin{array}{l}\text { Refe- } \\
\text { ren- } \\
\text { ces }\end{array}$} \\
\hline & \multirow{2}{*}{$\begin{array}{c}\text { Hyperme- } \\
\text { tabolism }\end{array}$} & \multirow{2}{*}{$\begin{array}{l}\text { Hypometa- } \\
\text { bolism }\end{array}$} & \multicolumn{4}{|c|}{ Cerebrum cortex } & \multirow{2}{*}{$\begin{array}{l}\text { Basal } \\
\text { Gan- } \\
\text { glia }\end{array}$} & \multirow{2}{*}{$\begin{array}{l}\text { Tha- } \\
\text { lamus }\end{array}$} & \multirow{2}{*}{$\begin{array}{l}\text { Cere- } \\
\text { bel- } \\
\text { lum }\end{array}$} & \multirow{2}{*}{$\begin{array}{l}\text { Brain- } \\
\text { stem }\end{array}$} & \multirow[b]{2}{*}{$\begin{array}{l}\text { Ante- } \\
\text { rior } \\
\text { cin- } \\
\text { gula- } \\
\text { te }\end{array}$} & & \\
\hline & & & $\begin{array}{c}\text { Fron- } \\
\text { tal }\end{array}$ & $\begin{array}{c}\text { Parie- } \\
\text { tal }\end{array}$ & $\begin{array}{l}\text { Tem- } \\
\text { poral }\end{array}$ & $\begin{array}{l}\text { Occi- } \\
\text { pital }\end{array}$ & & & & & & & \\
\hline $\begin{array}{l}\text { Alzheimer's } \\
\text { Disease }\end{array}$ & - & $\begin{array}{l}\text { predominantly } \\
\text { in posterior re- } \\
\text { gions: posterior } \\
\text { temporoparietal } \\
\text { association } \\
\text { cortex and po- } \\
\text { sterior cingulate } \\
\text { cortex }\end{array}$ & $\downarrow$ & $\begin{array}{c}\downarrow \\
\text { (spared } \\
\text { SMC) }\end{array}$ & $\begin{array}{l}\downarrow \text { (po- } \\
\text { sterior } \\
\text { part) }\end{array}$ & $\begin{array}{l}\text { Nor- } \\
\mathrm{mal} / \downarrow\end{array}$ & $\mathrm{N}$ & $\mathrm{N}$ & $\mathrm{N}$ & $\mathrm{N}$ & $\mathrm{N}$ & $\downarrow$ & $68-73$ \\
\hline $\begin{array}{l}\text { Frontotempo- } \\
\text { ral Dementia }\end{array}$ & - & $\begin{array}{l}\text { predominantly } \\
\text { in anterior } \\
\text { regions: frontal } \\
\text { lobes, anterior } \\
\text { temporal cortex } \\
\text { and anterior } \\
\text { cingulate cortex }\end{array}$ & $\downarrow$ & $\mathrm{N}$ & $\begin{array}{c}\downarrow \\
\text { (TP) }\end{array}$ & $\mathrm{N}$ & $N / \downarrow^{a}$ & $N / \downarrow^{a}$ & $\mathrm{~N}$ & $\mathrm{~N}$ & $\downarrow$ & $\mathrm{N}$ & $6,53,54$ \\
\hline $\begin{array}{l}\text { Dementia } \\
\text { with Lewy } \\
\text { bodies }\end{array}$ & - & $\begin{array}{l}\text { occipitoparietal } \\
\text { area with the } \\
\text { preservation of } \\
\text { the posterior } \\
\text { cingulate region } \\
\text { (cingulate island } \\
\text { sign) }\end{array}$ & $\downarrow$ & $\downarrow$ & $\downarrow$ & $\begin{array}{c}\downarrow \\
\text { (PVC) }\end{array}$ & $\mathrm{N} / \downarrow$ & $\downarrow$ & $\mathrm{N}$ & $\mathrm{N}$ & $\mathrm{N}$ & $\downarrow$ & $9,59,60$ \\
\hline $\begin{array}{l}\text { Idiopathic } \\
\text { Parkinson's } \\
\text { Disease }\end{array}$ & $\begin{array}{l}\text { dorsolateral } \\
\text { putamen, } \\
\text { globus pallidus, } \\
\text { thalami, ponti- } \\
\text { ne, cerebellar, } \\
\text { cortical motor } \\
\text { area }\end{array}$ & $\begin{array}{l}\text { dorsolateral } \\
\text { prefrontal } \\
\text { cortices and } \\
\text { parietooccipital } \\
\text { cortices }\end{array}$ & $\downarrow$ & $\downarrow$ & $\downarrow$ & $\downarrow$ & $\uparrow$ & $\uparrow$ & $\uparrow$ & $\uparrow$ & $\downarrow$ & $\mathrm{N}$ & $88-91$ \\
\hline $\begin{array}{l}\text { Multiple } \\
\text { System } \\
\text { Atrophy }\end{array}$ & $\begin{array}{l}\text { bilateral frontal } \\
\text { and superior } \\
\text { parietal cortices, } \\
\text { bilateral tha- } \\
\text { lamus }\end{array}$ & $\begin{array}{c}\text { bilateral dorso- } \\
\text { lateral putamen, } \\
\text { cerebellum and } \\
\text { pons }\end{array}$ & $\uparrow$ & $\uparrow$ & $\uparrow / \downarrow$ & $\downarrow$ & $\downarrow$ & $\uparrow$ & $\downarrow$ & $\downarrow$ & $\downarrow$ & $\mathrm{N}$ & $\begin{array}{c}60,88 \\
89,108 \\
109\end{array}$ \\
\hline $\begin{array}{l}\text { Progressive } \\
\text { Supranuc- } \\
\text { lear Palsy }\end{array}$ & $\begin{array}{l}\text { bilateral: cortical } \\
\text { motor areas, } \\
\text { parietal cortex, } \\
\text { thalamus and } \\
\text { caudate nuclei }\end{array}$ & $\begin{array}{c}\text { brainstem } \\
\text { (especially mid- } \\
\text { brain), midline } \\
\text { frontals regions }\end{array}$ & $\uparrow$ & $\uparrow$ & $\downarrow$ & $\mathrm{N}$ & $\uparrow$ & $\uparrow$ & $\mathrm{N}$ & $\downarrow$ & $\begin{array}{l}\downarrow \text { (pre- } \\
\text { domi- } \\
\text { nantly) }\end{array}$ & $\downarrow$ & $\begin{array}{c}60,88 \\
89\end{array}$ \\
\hline $\begin{array}{l}\text { Corticoba- } \\
\text { sal Degene- } \\
\text { ration }\end{array}$ & - & $\begin{array}{l}\text { asymmetrical, } \\
\text { contralaterally } \\
\text { to the most } \\
\text { affected side: } \\
\text { parietal cortices } \\
\text { and basal } \\
\text { ganglia }\end{array}$ & $\downarrow$ & $\downarrow$ & $\downarrow$ & $\mathrm{N}$ & $\downarrow$ & $\downarrow$ & $\mathrm{N}$ & $\downarrow$ & $\downarrow$ & $\mathrm{N}$ & $\begin{array}{c}88,89 \\
104,115 \\
116\end{array}$ \\
\hline $\begin{array}{l}\text { Amyotrop- } \\
\text { hic Lateral } \\
\text { Sclerosis }\end{array}$ & $\begin{array}{l}\text { midbrain, } \\
\text { temporal pole, } \\
\text { hippocampus } \\
\text { and cerebellum }\end{array}$ & $\begin{array}{l}\text { frontal, motor } \\
\text { and occipital } \\
\text { cortex }\end{array}$ & $\downarrow$ & $\downarrow$ & $\uparrow(\mathrm{TP})$ & $\downarrow$ & $\begin{array}{c}\downarrow \\
(\uparrow \mathrm{LGP})\end{array}$ & $\mathrm{N}$ & $\uparrow$ & $\begin{array}{l}\uparrow \text { (pre- } \\
\text { domi- } \\
\text { nantly } \\
\text { mid- } \\
\text { brain) }\end{array}$ & $\downarrow$ & $\mathrm{N}$ & $136-138$ \\
\hline
\end{tabular}

LGP — Lateral Globus Pallidus; TP — temporal pole; SMC — sensory motor cortex; PVC — primary visual cortex; $\downarrow$ - decreased metabolism; $\uparrow$ - increased metabolism; N — normal; . in advanced stage

variant [9]. Additionally, the retention of a tau radioligand, ${ }^{18} \mathrm{~F}-\mathrm{AV}$-1451, significantly differs between typical and atypical $\mathrm{AD}$ and also between visuospatial and aphasic (logopenic) $\mathrm{AD}[10,11]$. In a meta-analysis of ${ }^{18} \mathrm{~F}$-FDG PET studies with cognitively normal controls, the pooled sensitivity and specificity in distinguishing $\mathrm{AD}$ from healthy controls (HCs) were $86 \%$ and $86 \%$, respectively [12] ${ }^{18}$ F-FDG PET imaging has a superior diagnostic accuracy in distinguishing AD from non-demented patients or individuals with mild cognitive impairment (MCI) compared to other diagnostic methods 
such as clinical guideline, CSF biomarkers, MRI, CT and SPECT [13]. AD-related hypometabolism pattern correlates significantly with disease severity assessed with Mini-Mental State Examination (MMSE), Alzheimer's Disease Assessment Scale-Cognitive scales and Everyday Cognition scale $[14,15]$.

\section{$A \beta$ and tau tracers}

Although $A \beta$ and tau protein brain depositions are the neuropathological hallmarks of $\mathrm{AD}$, neither of them is $\mathrm{AD}$ specific. Positive $A \beta$ scans are also present in dementia with Lewy bodies (DLB), cerebral amyloid angiopathy (CAA), and in up to $35 \%$ of cognitively unimpaired individuals $>60$ years [16-18]. Positive tau protein scans are also seen in tau positive frontotemporal lobar degeneration (FTLD-tau), progressive supranuclear palsy (PSP), corticobasal degeneration (CBD), and chronic traumatic encephalopathy. Interestingly, FTLD with TDP43 (FTLD-TDP), which is a non-tau pathology disorder, presents positive tau protein scans. This suggests an off-target binding of the radiotracers [19-24]. On the other hand, negative AP PET scans are obtained in rare forms of AD with unusual amyloid plaques that cannot be detected with commonly used $A \beta$ tracers.

Developed in 1999, 2-(1-\{6-[(2-[F-18]fluoroethyl)(methyl) amino]-2-naphthyl\}ethylidene) malononitrile $\left({ }^{18} \mathrm{~F}\right.$-FDDNP) was the first PET radiotracer to be used effectively in the visualisation of $A D$ pathophysiology in living humans $[25,26]$. It non-selectively binds to both AP and NFTs, but is less sensitive for tau deposits detection compared to further-mentioned radiotracers. Global brain ${ }^{18} \mathrm{~F}$-FDDNP uptake is significantly higher in AD patients compared to HCs. Its binding in the anterior cingulate and frontal region correlates inversely with MMSE score, while the neocortex uptake strongly correlates with cell losses in the hippocampus [27,28]. A significantly lower global retention of ${ }^{18} \mathrm{~F}$-FDDNP has been shown in HCs compared to MCI and in MCI compared to AD [29].

\section{Tau tracers}

Post mortem histopathological studies have shown a stronger correlation of neuronal loss and MMSE score with NFTs compared to AP deposits [30,31]. The group of tau protein radiotracers include ${ }^{18} \mathrm{~F}-\mathrm{AV}$-1451 (T807), T808, ${ }^{18} \mathrm{~F}-\mathrm{THK}-5105$, ${ }^{18} \mathrm{~F}-\mathrm{THK}-5117,{ }^{18} \mathrm{~F}-\mathrm{THK}-5351$ and ${ }^{11} \mathrm{C}-\mathrm{PBB} 3$. High T807 binding is present in both $\mathrm{MCI}$ and $\mathrm{AD}$ patients, and is especially marked in the inferior temporal gyrus where its uptake correlates with MMSE and Clinical Dementia Rating scale sum of boxes (CDR-SOB) [32,33]. Its use is however limited due to a significant off-target binding, including iron, neuromelanin, and MAO [34-36]. ${ }^{18} \mathrm{~F}-\mathrm{THK}-5351$ retention differs significantly in $\mathrm{AD}$ compared to $\mathrm{HCs}$ or $\mathrm{MCI}$ and it correlates with neuropsychological tests in both $\mathrm{MCI}$ and $\mathrm{AD}$ patients. It also inversely correlates with the FDG uptake $[37,38] .{ }^{11} \mathrm{C}-\mathrm{PBB} 3 \mathrm{~A}$ neocortex retention is significantly higher in $\mathrm{AD}$ compared to HCs and its uptake in the frontal and temporo-parietal junctions correlates inversely with MMSE [39]. The short half-life time of this radiotracer restricts its clinical use, and a fluorine-18 labelled PBB3 is expected to be developed in the near future.

\section{$A \beta$ tracers}

A retention of A $\beta$ PET tracers highly correlates with brain biopsy findings $[40,41]$. The first $A \beta$ plaques $P E T$ radioligand was the Carbon-11-labelled Pittsburgh compound $\mathrm{B}\left({ }^{11} \mathrm{C}-\mathrm{PiB}\right)$ with a pilot human study performed in 2002 and the first peer-reviewed article published in $2004[42,43]$. The ${ }^{11} \mathrm{C}-\mathrm{PiB}$ retention in $\mathrm{AD}$ is most prominent in the frontal cortex, followed by the parietal, temporal and occipital cortex and the striatum, compared to $\mathrm{HCs}[43] .{ }^{11} \mathrm{C}-\mathrm{PiB}$ retention negatively correlates with glucose uptake but not with MMSE or CDR $[43,44]$. Other $A \beta$ amyloid tracers include fluorine-18-labelled radioligands such as florbetapir, florbetaben and flutemetamol, all approved for clinical use by the US Food and Drug Administration (FDA). An analysis of seven AD individuals showed a thorough agreement between visual reads of flutemetamol PET scans and histological brain biopsy findings [45]. In a meta-analysis of 19 studies, the pooled sensitivity and specificity rates in distinguishing $\mathrm{AD}$ from $\mathrm{HCs}$ for florbetapir were $89.6 \%$ and $87.2 \%$, and for florbetaben $89.3 \%$ and $87.6 \%$, respectively, while in a phase II trial with flutemetamol they were $93.1 \%$ and $93.3 \%$ [46, 47]. A prospective study of 211 patients suspected of early-onset dementia showed that the addition of flutemetamol PET imaging to clinical examination, medical history, laboratory tests, brain MRI and neuropsychological testing, increased the diagnostic confidence from $69 \% \pm 12 \%$ to $88 \% \pm 15 \%$. The study resulted in a change of diagnosis in $19 \%$ and initiation of treatments in $37 \%$ of patients with $\mathrm{AD}$ [48]. In the early stage of the disease, amyloid PET imaging showed as high an accuracy in AD diagnosis as $A \beta 42 /$ total tau or $A \beta 42 /$ hyperphosphorylated tau CSF. A combination of CSF and PET biomarkers were not however able to increase the diagnostic accuracy [49]. In recent years both flutemetamol and florbetapir have become widely available in the US and Western Europe and have been used in a number of clinical trials. Other accessible $\mathrm{A} \beta$ selective biomarkers clearly differentiating $\mathrm{AD}$ from HCs are BF-227 and ${ }^{18}$ F-AZD4694 (NAV4694) [50, 51].

\section{PET in differential diagnosis of $\mathrm{AD}$}

Determining the cause of dementia is challenging, even for specialists. Accurate diagnosis is essential because each dementia subtype has a specific mechanism, treatment, family risk, and prognosis.

$$
A D \text { vs FTD }
$$

Frontotemporal dementia (FTD) is a neurodegenerative disease characterised by progressive deficits in behaviour, executive functions, or language. Its pathological hallmark is the degeneration of the prefrontal and anterior temporal cortices [52]. Cognitive impairment may be absent in the prodromal phase with only behavioural changes, which can lead to an 
erroneous diagnosis of psychiatric disorder. The behavioural variant of FTD can also clinically overlap with the frontal variant of $\mathrm{AD}$ as both disorders develop behavioural changes. ${ }^{18}$ F-FDG PET imaging in FTD patients shows hypometabolism predominantly in anterior regions: frontal lobes, anterior temporal cortex and anterior cingulate cortex, while in $\mathrm{AD}$ the hypometabolism is present in posterior regions including posterior temporoparietal association cortex and posterior cingulate cortex $[6,53,54]$ (Tab. 2). The sensitivity and specificity rates for differentiating AD from FTD with ${ }^{18} \mathrm{~F}$-FDG PET imaging have been estimated at $99 \%$ and $65 \%$, respectively [55]. Interestingly, ${ }^{18} \mathrm{~F}$-FDG PET imaging is superior to clinical assessment in differentiating AD and FTD by an experienced dementia specialist, reaching a diagnostic accuracy of $89.6 \%$ [56]. As A $\beta$ protein depositions are not features of FTD, there is a significantly lower florbetapir uptake compared to $\mathrm{AD}$ [57]. A study performed in $62 \mathrm{AD}$ and $45 \mathrm{FTLD}$ patients showed a higher sensitivity rate for ${ }^{11} \mathrm{C}$-PiB-PET visual read $(89 \%$ vs $73 \%)$ and higher specificity for ${ }^{18} \mathrm{FDG}$ PET visual read $(83 \%$ vs 98\%) in differentiating AD from FTD [58].

\section{$A D$ vs $D L B$}

DLB accounts for $20 \%$ of late-onset dementias. Its pathological hallmark is the presence of Lewy bodies within the neocortical and limbic regions and usually deposits of AP and NFTs. It is characterised by cognitive fluctuations, visual hallucinations and spontaneous features of parkinsonism. DLB may present a clinical overlap with $\mathrm{AD}$ in terms of cognitive impairment with executive and memory dysfunction and spontaneous parkinsonism. The glucose uptake pattern in DLB is characterised by a predominant occipito-parietal hypometabolism with the preservation of the posterior cingulate region presenting a 'cingulate island sign' on PET scans (Tab. 2) [9, 59, 60]. Revised criteria for the clinical diagnosis of probable and possible DLB have included ${ }^{18}$ F-FDG PET imaging as a supportive biomarker. The sensitivity and specificity rates for differentiating DLB from FTD with ${ }^{18} \mathrm{~F}$-FDG imaging have been estimated to be $71 \%$ and $65 \%$, respectively [55]. Since the deposition of $A \beta$ is present in the majority of DLB patients, $A \beta$ tracers are not useful in differentiating DLB from AD. However, high neocortical A $\beta$ cortical deposits are associated with a shorter prodromal phase in DLB [16]. ${ }^{18} \mathrm{~F}-\mathrm{AV}-133$, a biomarker of dopaminergic nigrostratial function, has a $>95 \%$ accuracy in differentiating DLB from $\mathrm{AD}$ and significantly correlates with cognitive performance in DLB patients [61,62]. The combination of dopaminergic tracers and FDG has been shown to be useful in differentiating DLB from AD, Parkinson's disease (PD) and HCs [63]. Also, brain acetylcholinesterase (AChE) activity, measured with $\mathrm{N}-[11 \mathrm{C}]-$ methyl-4-piperidyl acetate $\left({ }^{11} \mathrm{C}-\mathrm{MP} 4 \mathrm{~A}\right)$, reveals a significant difference between $\mathrm{AD}$ and DLB [64].

\section{$A D$ vs $V D$}

Although vascular dementia (VD) is the biggest clinical challenge in differential diagnosis of $\mathrm{AD}$, it is primarily evaluated by MRI [65]. ${ }^{18}$ F-FDG PET scans reveal cortical and subcortical hypometabolism areas corresponding to signal changes in MRI.

In the most recent European Association of Nuclear Medicine (EANM) and European Academy of Neurology (EAN) recommendations for the use of brain FDG PET in neurodegenerative cognitive impairment and dementia, the panel agreed on recommending ${ }^{18} \mathrm{~F}$-FDG PET in diagnosing MCI due to AD, FTLD or DLB, in the diagnosis of atypical $\mathrm{AD}$ and pseudodementia, and in differentiating between $\mathrm{AD}$ and DLB, FTLD or VD, and between DLB and FTLD [66].

\section{PET in prognosis of $\mathrm{AD}$}

Patients with MCI are at a higher risk for developing AD, with an estimated conversion rate of $10 \%$ to $15 \%$ per year [67]. In a one-year follow-up study performed in $37 \mathrm{MCI}$ patients, all eight individuals who converted to AD showed reduced cerebral glucose metabolic rates in the inferior parietal cortex, in contrast to the non-converters [68]. Moreover, among APOE4 genotype positive groups, a prediction of conversion to $\mathrm{AD}$ reached the sensitivity of $100 \%$ and the specificity of $90 \%$. Bilateral hypometabolism in the medial temporal cortex is also linked to a higher risk of conversion, while hypometabolism in the dorsolateral frontal cortex is present in stable MCI patients $[69,70]$. The presence of the APOE4 gene in cognitively unimpaired individuals is linked with significant hypometabolism in posterior cingulate, parietal, temporal and prefrontal cortex as observed in the group with probable $\mathrm{AD}$ [71, 72]. A large meta-analysis that included six ${ }^{18}$ F-FDG-PET studies with 280 patients showed a ${ }^{18} \mathrm{~F}$-FDG PET imaging sensitivity of $88.9 \%$ and specificity of $84.9 \%$ in the prediction of conversion to $\mathrm{AD}$ in patients with $\mathrm{MCI}$. The results were more accurate than SPECT and structural MRI [73]. Positive ${ }^{11} \mathrm{C}-\mathrm{PiB}$ scans in MCI patients at baseline strongly predicted conversion to $\mathrm{AD}$, although negative ${ }^{11} \mathrm{C}-\mathrm{PiB}$ scans did not exclude a further conversion [74-76]. ${ }^{11} \mathrm{C}-\mathrm{PiB}$ PET imaging was able to clearly distinguish $\mathrm{MCI}$ from $\mathrm{AD}$ and $\mathrm{MCI}$ from $\mathrm{HCs}$, and to differentiate those groups better than ${ }^{18} \mathrm{~F}-\mathrm{FDG}$ PET imaging [77-79].

A combination of markers including hippocampal volumetry (Hippo), ${ }^{18}$ F-FDG PET, amyloid PET and CSF $\mathrm{A} \beta 42$ has a good predictive value in assessing the risk of conversion of MCI patients to AD. In a seven-year follow-up study, 73 patients were divided into four groups depending on biomarker positivity. The lowest conversion rate (5\%) was reported for A $\beta 42(-){ }^{18} \mathrm{~F}-\mathrm{FDG}$-PET(-) Hippo(-), while the highest (100\%) for concomitant A $\beta 42(+),{ }^{18} \mathrm{~F}-\mathrm{FDG}-\mathrm{PET}(+)$ and Hippo $(+)$. The latter was also found to convert in the shortest time [80].

\section{PET in progression and treatment of $\mathrm{AD}$}

${ }^{18}$ F-FDG-PET has been established as a sensitive marker of disease progression of $\mathrm{AD}$ in a one-year follow-up study. On the other hand, ${ }^{11} \mathrm{C}-\mathrm{PiB}$-PET retention remained stable 
in a two-year observation $[4,81]$. A significant decline in $\mathrm{AD}$-related glucose uptake pattern was observed in a one-year follow-up study in a non-treated group compared to a rivastigmine-treated group [82]. A similar outcome was obtained in a 24-week follow-up study with donepezil [83].

\section{Parkinson's disease}

$\mathrm{PD}$ is the second most common neurodegenerative disorder after AD. It is characterised by a dopaminergic neuronal loss in substantia nigra caused by intraneuronal proteinaceous inclusions, called Lewy bodies, mainly composed of $\alpha$-synuclein. The diagnosis of PD is based on clinical criteria including bradykinesia, rigidity, resting tremor and postural instability. With disease progression, non-motor features such as cognitive decline, depression, psychosis, sleep dysfunction and dysautonomia may also be present $[84,85]$.

\section{PET in diagnosis of PD}

The most commonly used radioligands in PD PET studies are ${ }^{18} \mathrm{~F}$-FDG and dopamine-specific radiotracers that can be divided into three groups: biomarkers of dopamine (DA) synthesis $\left({ }^{18} \mathrm{~F}\right.$-DOPA); biomarkers of synaptic dopamine transporters (DAT) $\left({ }^{11} \mathrm{C}\right.$-CFT, ${ }^{11} \mathrm{C}$-MP, ${ }^{11} \mathrm{C}$-FECIT, ${ }^{11} \mathrm{C}$-PE2I, ${ }^{18} \mathrm{~F}$-FP-CIT) and vesicle monoamine transporters (VMAT2) $\left({ }^{11} \mathrm{C}-\mathrm{DTBZ},{ }^{18} \mathrm{~F}-\mathrm{AV}-133\right)$; and biomarkers of postsynaptic dopaminergic function (D2/3 receptors, D2/3) $\left({ }^{11} \mathrm{C}\right.$-raclopride, ${ }^{11} \mathrm{C}$-n-methylspiperone, ${ }^{11} \mathrm{C}$-FLB $457,{ }^{18} \mathrm{~F}$-fallypride, ${ }^{18} \mathrm{~F}$-desmethoxyfallypride) (Tab. 1). Other radioligands used in PD PET imaging include microglia activation biomarkers $\left({ }^{11} \mathrm{C}\right.$-(R)-PK11195) and AChE activation biomarkers $\left({ }^{11} \mathrm{C}\right.$ -MP4P) [86, 87].

$$
{ }^{18} \text { F-FDG }
$$

A PD-related pattern is characterised by hypermetabolism in the basal ganglia, ventral thalamus, pons and cerebellum with concurrent hypometabolism in the dorsolateral prefrontal, posterior parietal and occipital cortex [88-91] (Tab. 2). Its expression correlates positively with Hoehn and Yahr (H\&Y) and Unified Parkinson's disease rating scale (UPDRS) motor scores [90].

\section{Dopamine-specific tracers}

Radiotracers assessing dopaminergic function are useful in PD diagnosis. There is a significant reduction of ${ }^{18} \mathrm{~F}$-DOPA uptake in the caudate nucleus and putamen and the ${ }^{11} \mathrm{C}-\mathrm{CFT}$ uptake in the posterior putamen compared to HCs [92, 93]. Interestingly, a different ${ }^{11} \mathrm{C}$-CFT distribution occurs in young-onset $\mathrm{PD}$, where caudate nuclei are more spared compared to putamen. The late-onset subtype is characterised by a more uniform pattern [94]. As dopaminergic tracers' retention inversely correlates with motor disability (UPDRS motor scores in case of ${ }_{18} \mathrm{~F}-\mathrm{DOPA},{ }_{11} \mathrm{C}$-CFT, ${ }_{18} \mathrm{~F}-\mathrm{FP}-\mathrm{CIT}$ and $\left.{ }_{18} \mathrm{~F}-\mathrm{DTBZ}\right)$, these may be useful in the evaluation of disease progression [94-96]. Furthermore, the retention of DAT $\left({ }^{11} \mathrm{C}-\mathrm{CFT}\right)$ and VMAT2 $\left({ }^{18} \mathrm{~F}-\mathrm{DTBZ}\right)$ correlates with disease duration $[94,96]$.

Due to up-regulation of $\mathrm{D} 2$ receptors, D2/D3 tracer uptake is usually increased in PD [97]. A recent publication considering 18F-fallypride, one of the D2/D3 tracers, presented a significantly reduced retention in PD compared to HCs and a correlation between its uptake in the putamen and globus pallidus with UPDRS [98].

\section{Non-motor dysfunctions in PD}

PET has also been used in the assessment of psycho-behavioural and olfactory dysfunction. Limbic AChE activity correlates positively with cognitive and memory functions, but not with visuospatial functions [87]. While PD-dementia (PDD) is associated with a generalised cortical hypometabolism, PD-MCI patients develop hypometabolism in the temporoparietooccipital junction and the frontal cortex [99-101]. ${ }^{11} \mathrm{C}$-(R)-PK11195-uptake, reflecting microglia activation, is significantly increased in cingulate, striatum and neocortex in PDD compared to HCs, and in the left parietal lobe in PDD compared to non-demented PD patients, and correlates inversely with MMSE score [86].

Hyposmic PD shows significantly reduced DAT $\left({ }^{18} \mathrm{~F}-\mathrm{FP}\right.$ -CIT) binding in bilateral caudates and in left anterior and posterior putamen compared to normosmic PD patients [96]. Also the degree of DAT uptake $\left({ }^{18} \mathrm{~F}\right.$-FP-CIT, ${ }^{11} \mathrm{C}-\beta$-CFT) in the hippocampus, amygdala and striatum, VMAT2 $\left({ }^{11} \mathrm{C}\right.$-dihydrotetrabenazine) in the striatum and $\mathrm{AChE}$ activity tracer $\left({ }^{11} \mathrm{C}-\mathrm{MP} 4 \mathrm{P}\right)$ in the hippocampus, amygdala and neocortex correlates with the University of Pennsylvania Smell Identification Test (UPSIT) scores $[87,102,103]$.

\section{PET in differential diagnosis of PD}

Due to its different prognosis and response to pharmacological and surgical treatment, it is especially important to differentiate PD from other diseases with parkinsonian features (known as atypical parkinsonian syndromes, APS), such as multiple system atrophy (MSA) and PSP, accounting together for $80 \%$ of misdiagnosed PD, as well as CBD and DLB [104].

Putamen hypermetabolism is one of the crucial elements of PDRP and the only feature distinguishing PD from APS $[88,89]$. However, along with disease progression, the metabolism of the putamen normalises turning hypometabolic in the advanced stage, which may decrease its usefulness in differentiating a diagnosis $[88,89,105]$. An analysis of putamen-related parameters including posterior putamen binding, posterior-to-anterior putamen ratio, and posterior putamen-to-caudate with D2/3 receptor ligand (18F-DMFP) results in high sensitivity, specificity and accuracy (92\%, 96\% and 94\%, respectively) in distinguishing PD from APS $[106,107]$. 


\section{PD vs MSA}

MSA is characterised by a combination of parkinsonism, autonomic dysfunction, and cerebellar ataxia. Bilateral cerebellar and putaminal hypometabolism are distinguishing PET features of the disease $[60,88,89]$. Cerebellar hypometabolism is present in both patients with cerebellar dysfunction (MSA$-C)$ and those without ataxia (MSA-P) [89]. Although not all MSA-P patients present cerebellar hypometabolism, it is rarely observed in other parkinsonian condition. Only a few MSA patients develop parietal hypometabolism, while it is a common finding in non-demented PD patients [108]. A significant correlation has been found between the degree of cerebellum and pons hypometabolism and cerebral ataxia and autonomic dysfunction. No such correlation has been observed between striatal hypometabolism and the severity of parkinsonism [109]. ${ }^{18}$ F-FDG-PET sensitivity/specificity rates in the clinical diagnosis of MSA are 76\%/98\% with visual reading, and 96\%/99\% with statistical parametric mapping (SPM)-supported reading, respectively [89]. MSA-P patients present more pronounced DAT $\left({ }^{11} \mathrm{C}-\mathrm{CFT}\right)$ reduction compared to MSA-C [110].

\section{PD vs PSP}

PSP is clinically characterised by a vertical gaze dysfunction, extrapyramidal features and cognitive decline. The specific glucose uptake pattern in PSP is characterised by bilateral reduction of metabolism in midline frontal regions and in the brainstem $[60,88,89]$. The evaluated sensitivity and specificity rates in the clinical diagnosis of PSP with the ${ }^{18} \mathrm{~F}$-FDG-PET visual reading are $60 \%$ and $96 \%$, respectively, and with SPM-supported reading they account for $85 \%$ and 99\% [89]. Caudate ${ }^{18} \mathrm{~F}$-dopa uptake is significantly lower in PSP compared to PD, and equally decreased in anterior and posterior putamen in PSP, in contrast to PD where the anterior putamen is relatively spared [92]. Since PSP is a tauopathy, tau radiotracers are useful in differentiating PSP from PD. ${ }^{18} \mathrm{~F}$-FDDNP shows a distinctive pattern at early disease stages and its binding in the frontal lobe correlates with the PSP rating scale (PSPRS) score [111]. High ${ }^{18} \mathrm{~F}-\mathrm{AV}$-1451 uptake within the putamen, pallidum, thalamus, midbrain and dentate nucleus of the cerebellum is observed in PSP compared to HCs, and it also correlates with the PSP clinical severity score [112-114]. Compared to healthy individuals, PSP is also characterised by a higher ${ }^{11} \mathrm{C}-\mathrm{PBB}$ uptake in globus pallidus, putamen, thalamus, subthalamus, midbrain, pons and peri-rolandic areas [23].

\section{$P D$ vs $C B D$}

$\mathrm{CBD}$ is a neurodegenerative disease classified as a primary tauopathy characterised by progressive asymmetric rigidity and apraxia accompanied by other cortical and extrapyramidal dysfunction features [115]. The specific glucose uptake pattern in CBD is characterised by asymmetric basal ganglia and cerebral cortical hypometabolism, mainly expressed in frontoparietal area, contralateral to the clinically more affected side, and a bilateral occipital region hypermetabolism [88, $89,116]$. The sensitivity and specificity rates in the clinical diagnosis of CBD with ${ }^{18}$ F-FDG-PET visual reading are $91 \%$ and $92 \%$, respectively, and with SPM-supported reading they account for $91 \%$ and $99 \%$ [89]. The patterns of glucose and levodopa uptake differ in the early stages of CBD and PD [118]. Compared to HCs, $\mathrm{CBD}$ is characterised by a high retention of ${ }^{11} \mathrm{C}-\mathrm{PBB} 3$ in the peri-rolandic areas, supplementary motor area, subthalamus and midbrain, with greater binding in basal ganglia contralaterally to the affected side [23]. Both ${ }^{18} \mathrm{~F}-\mathrm{AV}$ 1451 and ${ }^{18} \mathrm{~F}$-THK-5351 retention patterns are able to clearly differentiate $\mathrm{CBD}$ from $\mathrm{HCs}$ and $\mathrm{AD}$, while ${ }^{18} \mathrm{~F}-\mathrm{AV}$-1451 - from PSP $[118,119]$.

Interestingly, ${ }^{18} \mathrm{~F}$-FDG PET imaging has been found to be as predictive in risk stratification of APS as a one-year clinical follow-up. It was also superior to SPECT in differential diagnosis of APS [120, 121].

\section{PET in assessment of treatment efficacy in PD}

Long-term PD treatment results in late motor complications, such as fluctuations and dyskinesia. Patients who are at risk of developing 'wearing-off' fluctuations present significantly less expressed dopamine transporter activity in the putamen at baseline. Compared to individuals not experiencing 'wearing-off', they have been found to have a three times higher synaptic level of dopamine (measured with ${ }^{11} \mathrm{C}$-raclopride) at one hour and no changes at four hours after oral administration of levodopa [122-124]. Marked DAT impairment in the posterior putamen at baseline is significantly associated with early appearance of levodopa-induced bradykinesia [125]. The long-time effect of PD pharmacological treatment assessed with PET studies showed a slower loss of striatal dopamine storage in patients treated with ropinirole compared to levodopa [126]. PD-related pattern (PDRP) decreases after subthalamotomy, deep brain stimulation (DBS) of the subthalamic nucleus (STN) and levodopa treatment, showing a correlation with clinical improvement after therapy [127, 128]. PET studies have been introduced into clinical trials including gene or cell therapy, but their outcomes do not always correlate with clinical improvement [129].

\section{PET in prognosis of $\mathrm{PD}$}

Dysfunction of nucleus accumbens and orbitofrontal cortex on the clinically intact side, presented with reduced dopamine transporter radiotracer $\left({ }^{11} \mathrm{C}-\mathrm{CFT}\right)$ uptake, positively correlates with the interval of developing bilateral parkinsonism [130]. Idiopathic rapid eye movement sleep behaviour disorder (iRBD) is considered to be one of the predictors of developing PD. In a clinical follow-up study of 10 iRBD patients and $10 \mathrm{HCs}$ the phenoconversion to PD/DLB was more likely in individuals with high PDRP at baseline. In contrast, the iRBD patients who developed MSA 2-4 years later had 
not expressed the PDRP at baseline $[131,132]$. De novo PD patients with RBD present more pronounced hypometabolism in posterior cortical regions and anterior cortical regions of the more affected side, as well as a dopaminergic impairment of caudate nuclei and putamen measured with DAT uptake compared to non-RBD PD patients [133, 134]. Interestingly, iRPD patients present a significantly higher putamen/caudate ratio than both RBD-PD and non-RBD PD [134].

\section{Amyotrophic lateral sclerosis}

Amyotrophic lateral sclerosis (ALS) is a neurodegenerative disease affecting the upper and lower motor neuron resulting in progressive neuromuscular weakness. The pathogenesis of the disease still remains unclear. Approximately $50 \%$ of patients develop language and executive dysfunction in the course of the disease, while 15\% develop FTD (FTD-ALS) [135].

\section{PET in diagnosis of ALS}

\section{${ }^{18} \mathrm{~F}-\mathrm{FDG}$}

The majority of ALS PET studies have been performed with ${ }^{18} \mathrm{~F}$-FDG. ALS glucose-uptake pattern is characterised by hypometabolism in frontal, motor, and occipital cortex and hypermetabolism in cerebellum, midbrain, temporal pole and hippocampus [136-138]. In a study with 195 ALS patients, significantly more expressed hypometabolism in left motor and premotor cortex was present in bulbar as compared to spinal onset patients [137]. In another study with 13 bulbar and 19 spinal onset patients, similar patterns were observed, but with no significant difference between the two groups. In ALS patients with spinal onset, there was a relative hypermetabolism in the right midbrain compared to HCs [136]. No meta-analysis of the sensitivity and specificity in discriminating ALS patients from controls has been performed to date. A one-year follow-up study performed in 195 ALS patients and 40 controls showed a sensitivity of $95.4 \%$ and specificity of $82.5 \%$ in discriminating both groups with ${ }^{18} \mathrm{~F}-\mathrm{FDG}$ imaging at baseline [137].

\section{Other tracers}

A significantly lower uptake of a GABA-A biomarker $\left({ }^{11} \mathrm{C}\right.$-flumazenil) has been found in the prefrontal, parietal, visual association and left motor and premotor cortex of ALS patients compared to HCs [139]. This may be due to the loss or dysfunction of inhibitory GABA-ergic neurons in ALS patients. Compared to HCs, sporadic ALS (sALS) show decreased cortical ${ }^{11} \mathrm{C}$-flumazenil uptake predominantly in the premotor regions, motor cortex and posterior motor associated areas. Patients with ALS-linked D90A SOD1 mutation show a decreased radiotracer uptake in the left frontotemporal junction and anterior cingulate of the dominant hemisphere $[140] .{ }^{11} \mathrm{C}$ flumazenil uptake in sALS correlates with upper motor neuron (UMN) damage, but not with revised ALS functional rating scale (ALSFRS-R), while in ALS SOD1 D90A homozygotes it correlates with ALSFRS-R and disease duration, but not with UMN damage. Patients harbouring a C9orf72 dynamic mutation, the most frequent genetic cause for ALS, present relatively more expressed hypometabolism in the thalamus and posterior cingulate compared to C9orf72-negative individuals [141]. In a study performed in 70 ALS patients (11 C9orf72-positive, 59 C9orf72-negative, $20 \mathrm{HCs}$ ), the sensitivity, specificity, and accuracy rates in distinguishing each patient group from HCs were $89.8 \%, 85.0 \%$, and $88.6 \%$ in C9orf72-negative ALS, and $90.9 \%, 100 \%$, and $96.8 \%$, in C9orf72-positive cases, respectively [141]. Microglia activation, typically increased in ALS motor system, can be assessed with ${ }^{11} \mathrm{C}-(\mathrm{R})-\mathrm{PK} 11195$ and ${ }^{11} \mathrm{C}-\mathrm{PBR} 28$ radioligands. In a group of 10 ALS patients and $14 \mathrm{HCs}$, a significantly higher ${ }^{11} \mathrm{C}$-(R)-PK11195 binding was found in motor cortex, pons, dorsolateral prefrontal cortex and thalamus in ALS patients compared to HCs. There was a correlation between radiotracer uptake in the motor cortex and UMN damage [142]. A significantly increased ${ }^{11} \mathrm{C}-\mathrm{PBR} 28$ binding was also observed in the precentral gyrus of ALS patients compared to HCs [143]. ${ }^{11} \mathrm{C}-\mathrm{PBR}$ negatively correlated with ALSFRS-R scale and positively with UMN damage, but there was no correlation with disease duration [143]. Bulbar onset patients showed increased ${ }^{11} \mathrm{C}$-PBR uptake in the brainstem while limb onset in the precentral gyri [143]. Neuronal loss in the central nervous system in ALS patients is accompanied by actrocytosis. As MAO-B is primarily located in astrocytes, actrocytosis activation can be measured with MAO-B radiotracers such as ${ }^{11} \mathrm{C}$-deprenyl-D2 $\left({ }^{11} \mathrm{C}-\mathrm{DED}\right)$. A significantly increased binding of ${ }^{11} \mathrm{C}$-DED has been observed in the pons and white matter of ALS patients compared to HCs [144].

\section{PET in differential diagnosis of ALS ALS vs FTD-ALS}

FTD-ALS patients present more expressed hypometabolism including bilateral premotor, frontal, anterior prefrontal cortex with left predominance, lateral prefrontal and orbitofrontal cortex compared to ALS cognitively normal individuals. Significantly different patterns are also observed between cognitively normal and impaired ALS patients not fulfilling FTD criteria and cognitively impaired non-FTD ALS and ALS-FTD [145]. FTD-ALS patients present hypometabolism in the frontal area, while FTD alone have hypometabolism both in the frontal and temporal areas with a more symmetric pattern presented in FTD-ALS patients [146].

\section{ALS vs PLS vs PMA}

There is a significantly more expressed hypometabolism in the prefrontal cortex and posterior cingulate of ALS compared to primary lateral sclerosis (PLS) patients. It is also significantly less expressed in the primary sensorimotor cortex of PLS compared to ALS. The sensitivity and specificity rates allowing a distinction between PLS and HCs are $57.1 \%$ and $100 \%$, respectively [141]. ${ }^{11} \mathrm{C}$-flumazenil binding in anterior frontal and orbito-frontal regions was relative lower in both sALS 
and D90A SOD1 ALS patients compared to PLS [147]. The glucose-uptake pattern in progressive muscular atrophy (PMA) did not differ from classic ALS, except for a less expressed hypometabolism in the motor cortex and the thalamus [141].

\section{PET in prognosis of ALS}

Extensive hypometabolism in the prefrontal or anterior temporal areas is associated with a significantly shorter survival in C9orf72-negative ALS patients [141]. As mentioned before, a reduced ${ }^{11} \mathrm{C}$-flumazenil uptake in SOD1 D90A homozygotes has been shown to correlate with disease duration [140]. A significantly increased uptake of an oxidative stress biomarker, ${ }^{62} \mathrm{Cu}$-ATSM, in the bilateral cortices around the central sulcus has been observed in ALS patients compared to HCs. It negatively correlated with ALSFRS-R [148].

\section{Conclusion}

PET imaging is a useful diagnostic tool in the assessment of various neurodegenerative diseases (Tab. 2). Specific glucose uptake patterns observed in $\mathrm{AD}$ and in other dementias enable physicians to diagnose and differentiate these disorders with high degrees of sensitivity and specificity. A group of accessible $A \beta$ and NFTs radiotracers present high uptake in AD. ${ }^{18}$ F-FDG-PET imaging can help predict MCI-AD conversion. The glucose uptake patterns characteristic for PD and APS permit the distinction of a number of disorders with parkinsonian features.

This is especially important in cases with different prognoses and responses to treatment. Dopamine radiotracers correlate well with disease severity and can predict further drug-induced motor implications. ${ }^{18} \mathrm{~F}-\mathrm{FDG}$ and ${ }^{11} \mathrm{C}$-flumazenil imaging seems to be helpful in the diagnosis of ALS and in differentiating it from PLS as both diseases differ in prognosis.

In recent years, PET imaging has become widely accessible not only in scientific but also in clinical settings. The use of PET in the diagnostic process of neurodegenerative diseases provides the opportunity to decrease diagnosis delay, increase diagnostic confidence, and monitor treatment efficiency.

Acknowledgement: This paper was partially supported by grant 5/JPND/2011 SOPHIA from the EU Joint Programme-Neurodegenerative Disease Research Project funded by the National Centre for Research and Development of Poland.

\section{References}

1. Rabinovici GD. The translational journey of brain $\beta$-amyloid imaging: from positron emission tomography to autopsy to clinic. JAMA Neurol. 2015; 72(3): 265-266, doi: 10.1001/jamaneurol.2014.4143, indexed in Pubmed: 25621934.

2. Zhu A, Lee D, Shim H. Metabolic positron emission tomography imaging in cancer detection and therapy response. Semin Oncol. 2011;
38(1): 55-69, doi: 10.1053/j.seminoncol.2010.11.012, indexed in Pubmed: 21362516.

3. Prince M, Wimo A, Guerchet M, et al. Alzheimer's Disease International; London: 2015. World Alzheimer Report 2015. The Global Impact of Dementia. An analysis of prevalence, incidence, costs and trends. World Alzheimer's Report.

4. Alexander GE, Chen K, Pietrini P, et al. Longitudinal PET Evaluation of Cerebral Metabolic Decline in Dementia: A Potential Outcome Measure in Alzheimer's Disease Treatment Studies. Am J Psychiatry. 2002; 159(5): 738-745, doi: 10.1176/appi.ajp.159.5.738, indexed in Pubmed: 11986126.

5. Mosconi L. Brain glucose metabolism in the early and specific diagnosis of Alzheimer's disease. FDG-PET studies in $\mathrm{MCl}$ and AD. Eur J Nucl Med Mol Imaging. 2005; 32(4): 486-510, doi: 10.1007/s00259005-1762-7, indexed in Pubmed: 15747152.

6. Minoshima S, Giordani B, Berent S, et al. Metabolic reduction in the posterior cingulate cortex in very early Alzheimer's disease. Ann Neurol. 1997; 42(1): 85-94, doi: 10.1002/ana.410420114, indexed in Pubmed: 9225689.

7. Herholz K, Salmon E, Perani D, et al. Discrimination between Alzheimer dementia and controls by automated analysis of multicenter FDG PET. Neuroimage. 2002; 17(1): 302-316, indexed in Pubmed: 12482085.

8. Kim EJ, Cho SS, Jeong Y, et al. Glucose metabolism in early onset versus late onset Alzheimer's disease: an SPM analysis of 120 patients. Brain. 2005; 128(Pt 8): 1790-1801, doi: 10.1093/brain/awh539, indexed in Pubmed: 15888536.

9. Nestor PJ, Altomare D, Festari C, et al. EANM-EAN Task Force for the Prescription of FDG-PET for Dementing Neurodegenerative Disorders. Clinical utility of FDG-PET for the differential diagnosis among the main forms of dementia. Eur J Nucl Med Mol Imaging. 2018; 45(9): 1509-1525, doi: 10.1007/s00259-018-4035-y, indexed in Pubmed: 29736698.

10. Whitwell J, Graff-Radford J, Tosakulwong N, et al. [18 F]AV-1451 clustering of entorhinal and cortical uptake in Alzheimer's disease. Annals of Neurology. 2018; 83(2): 248-257, doi: 10.1002/ana.25142.

11. Tetzloff KA, Graff-Radford J, Martin PR, et al. Regional Distribution, Asymmetry, and Clinical Correlates of Tau Uptake on [18F] AV-1451 PET in Atypical Alzheimer's Disease. J Alzheimers Dis. 2018; 62(4): 1713-1724, doi: 10.3233/JAD-170740, indexed in Pubmed: 29614676.

12. Patwardhan MB, McCrory DC, Matchar DB, et al. Alzheimer disease: operating characteristics of PET-a meta-analysis. Radiology. 2004; 231(1): 73-80, doi: 10.1148/radiol.2311021620, indexed in Pubmed: 15068942.

13. Bloudek LM, Spackman DE, Blankenburg M, et al. Review and metaanalysis of biomarkers and diagnostic imaging in Alzheimer's disease. J Alzheimers Dis. 2011; 26(4): 627-645, doi: 10.3233/JAD2011-110458, indexed in Pubmed: 21694448.

14. Herholz K, Westwood S, Haense C, et al. Evaluation of a calibrated (18)F-FDG PET score as a biomarker for progression in Alzheimer disease and mild cognitive impairment. J Nucl Med. 2011; 52(8): 1218-1226, doi: 10.2967/jnumed.111.090902, indexed in Pubmed: 21764801.

15. Hsu JL, Hsu WC, Chang CC, et al. Everyday cognition scales are related to cognitive function in the early stage of probable Alzheimer's disease and FDG-PET findings. Sci Rep. 2017; 7(1): 1719, doi: 10.1038/ s41598-017-01193-6, indexed in Pubmed: 28496183. 
16. Rowe CC, Ng S, Ackermann U, et al. Imaging beta-amyloid burden in aging and dementia. Neurology. 2007; 68(20): 17181725, doi: 10.1212/01.wnl.0000261919.22630.ea, indexed in Pubmed: 17502554.

17. Johnson KA, Gregas M, Becker JA, et al. Imaging of amyloid burden and distribution in cerebral amyloid angiopathy. Ann Neurol. 2007; 62(3): 229-234, doi: 10.1002/ana.21164, indexed in Pubmed: 17683091.

18. Chételat $\mathrm{G}$, La Joie R, Villain $\mathrm{N}$, et al. Amyloid imaging in cognitively normal individuals, at-risk populations and preclinical Alzheimer's disease. Neuroimage Clin. 2013; 2: 356-365, doi: 10.1016/j. nicl.2013.02.006, indexed in Pubmed: 24179789.

19. Spina S, Schonhaut DR, Boeve BF, et al. Frontotemporal dementia with the V337M mutation: Tau-PET and pathology correlations. Neurology. 2017; 88(8): 758-766, doi: 10.1212/WNL.0000000000003636, indexed in Pubmed: 28130473.

20. Lowe VJ, Curran G, Fang P, et al. An autoradiographic evaluation of AV-1451 Tau PET in dementia. Acta Neuropathol Commun. 2016; 4(1): 58, doi: 10.1186/s40478-016-0315-6, indexed in Pubmed: 27296779.

21. Tripathi M, Dhawan V, Peng S, et al. Differential diagnosis of parkinsonian syndromes using F-18 fluorodeoxyglucose positron emission tomography. Neuroradiology. 2013; 55(4): 483-492, doi: 10.1007/ s00234-012-1132-7, indexed in Pubmed: 23314836.

22. Maruyama M, Shimada H, Suhara T, et al. Imaging of tau pathology in a tauopathy mouse model and in Alzheimer patients compared to normal controls. Neuron. 2013; 79(6): 1094-1108, doi: 10.1016/j. neuron.2013.07.037, indexed in Pubmed: 24050400.

23. Shinotoh $\mathrm{H}$, Shimada $\mathrm{H}$, Hirano $\mathrm{S}$, et al. IMAGING OF TAU PATHOLOGY IN PATIENTS WITH NON-ALZHEIMER'S DISEASE TAUOPATHIES BY [11C]PBB3-PET. Alzheimer's \& Dementia. 2014; 10(4): P6-P7, doi: 10.1016/j.jalz.2014.04.030.

24. Barrio JR, Small GW, Wong KP, et al. In vivo characterization of chronic traumatic encephalopathy using [F-18]FDDNP PET brain imaging. Proc Natl Acad Sci U S A. 2015; 112(16): E2039-E2047, doi: 10.1073/pnas.1409952112, indexed in Pubmed: 25848027.

25. Barrio JR, Huang S-C, Cole G, et al. PET imaging of tangles and plaques in Alzheimer disease with a highly hydrophobic probe. $J$ Labelled Comp Radiopharm. 1999; 42: S194-S195.

26. Agdeppa ED, Kepe V, Shoghi-Jadid K, et al. In vivo and in vitro labeling of plaques and tangles in the brain of an Alzheimer's disease patient: a case study. J Nucl Med. 2001; 42: 65P.

27. Tauber C, Beaufils E, Hommet C, et al. Brain [18F]FDDNP binding and glucose metabolism in advanced elderly healthy subjects and Alzheimer's disease patients. J Alzheimers Dis. 2013; 36(2): 311-320, doi: 10.3233/JAD-122068, indexed in Pubmed: 23609763.

28. Barrio JR, Kepe V, Satyamurthy N, et al. Amyloid and tau imaging, neuronal losses and function in mild cognitive impairment. J Nutr Health Aging. 2008; 12(1): 61S-65S, indexed in Pubmed: 18165848.

29. Small GW, Kepe V, Ercoli LM, et al. PET of brain amyloid and tau in mild cognitive impairment. N Engl J Med. 2006; 355(25): 2652-2663, doi: 10.1056/NEJMoa054625, indexed in Pubmed: 17182990.

30. Giannakopoulos P, von Gunten A, Kövari E, et al. Tangle and neuron numbers, but not amyloid load, predict cognitive status in Alzheimer's disease. Neurology. 2003; 60(9): 1495-1500, indexed in Pubmed: 12743238.

31. Gómez-Isla T, Price JL, McKeel DW, et al. Profound loss of layer II entorhinal cortex neurons occurs in very mild Alzheimer's disease. J Neurosci. 1996; 16(14): 4491-4500, indexed in Pubmed: 8699259.
32. Johnson KA, Schultz A, Betensky RA, et al. Tau positron emission tomographic imaging in aging and early Alzheimer disease. Ann Neurol. 2016; 79(1): 110-119, doi: 10.1002/ana.24546, indexed in Pubmed: 26505746.

33. Chien DT, Bahri S, Szardenings AK, et al. Early clinical PET imaging results with the novel PHF-tau radioligand [F-18]-T807. J Alzheimers Dis. 2013; 34(2): 457-468, doi: 10.3233/JAD-122059, indexed in Pubmed: 23234879

34. Choi JY, Cho H, Ahn SJ, et al. Off-Target F-AV-1451 Binding in the Basal Ganglia Correlates with Age-Related Iron Accumulation. J Nucl Med. 2018; 59(1): 117-120, doi: 10.2967/jnumed.117.195248, indexed in Pubmed: 28775201.

35. Hansen AK, Knudsen K, Lillethorup TP, et al. In vivo imaging of neuromelanin in Parkinson's disease using 18F-AV-1451 PET. Brain. 2016; 139(Pt 7): 2039-2049, doi: 10.1093/brain/aww098, indexed in Pubmed: 27190023.

36. Lemoine L, Leuzy A, Chiotis K, et al. Tau positron emission tomography imaging in tauopathies: The added hurdle of off-target binding. Alzheimers Dement (Amst). 2018; 10: 232-236, doi: 10.1016/j. dadm.2018.01.007, indexed in Pubmed: 29780868.

37. Harada R, Okamura N, Furumoto S, et al. 18F-THK5351: A Novel PET Radiotracer for Imaging Neurofibrillary Pathology in Alzheimer Disease. J Nucl Med. 2016; 57(2): 208-214, doi: 10.2967/jnumed.115.164848, indexed in Pubmed: 26541774.

38. Kang JM, Lee SY, Seo S, et al. Tau positron emission tomography using [F]THK5351 and cerebral glucose hypometabolism in Alzheimer's disease. Neurobiol Aging. 2017; 59: 210-219, doi: 10.1016/j.neurobiolaging.2017.08.008, indexed in Pubmed: 28890300.

39. Shimada $\mathrm{H}$, Kitamura S, Shinotoh $\mathrm{H}$, et al. Association between $A \beta$ and tau accumulations and their influence on clinical features in aging and Alzheimer's disease spectrum brains: A [ 11 C]PBB3-PET study. Alzheimer's \& Dementia: Diagnosis, Assessment \& Disease Monitoring. 2017; 6: 11-20, doi: 10.1016/j.dadm.2016.12.009.

40. Bacskai BJ, Frosch MP, Freeman SH, et al. Molecular imaging with Pittsburgh Compound B confirmed at autopsy: a case report. Arch Neurol. 2007; 64(3): 431-434, doi: 10.1001/archneur.64.3.431, indexed in Pubmed: 17353389.

41. Ikonomovic MD, Klunk WE, Abrahamson EE, et al. Post-mortem correlates of in vivo PiB-PET amyloid imaging in a typical case of Alzheimer's disease. Brain. 2008; 131(Pt 6): 1630-1645, doi: 10.1093/ brain/awn016, indexed in Pubmed: 18339640.

42. Engler $\mathrm{H}$, Nordberg A, Blomqvist $\mathrm{G}$, et al. First human study with a benzothiazole amyloid-imaging agent in Alzheimer's disease and control subjects. Neurobiol Aging. 2002; 23(1S): S429.

43. Klunk WE, Engler $\mathrm{H}$, Nordberg $\mathrm{A}$, et al. Imaging brain amyloid in Alzheimer's disease with Pittsburgh Compound-B. Ann Neurol. 2004; 55(3): 306-319, doi: 10.1002/ana.20009, indexed in Pubmed: 14991808.

44. Okamura N, Furumoto S, Fodero-Tavoletti MT, et al. Non-invasive assessment of Alzheimer's disease neurofibrillary pathology using $18 \mathrm{~F}-$ THK5105 PET. Brain. 2014; 137(Pt 6): 1762-1771, doi: 10.1093/ brain/awu064, indexed in Pubmed: 24681664.

45. Wolk DA, Grachev ID, Buckley C, et al. Association between in vivo fluorine 18-labeled flutemetamol amyloid positron emission tomography imaging and in vivo cerebral cortical histopathology. Arch Neurol. 2011; 68(11): 1398-1403, doi: 10.1001/archneurol.2011.153, indexed in Pubmed: 21747004

46. Yeo JM, Waddell B, Khan Z, et al. A systematic review and metaanalysis of (18)F-labeled amyloid imaging in Alzheimer's disease. 
Alzheimers Dement (Amst). 2015; 1(1): 5-13, doi: 10.1016/j. dadm.2014.11.004, indexed in Pubmed: 27239488.

47. Vandenberghe R, Van Laere K, Ivanoiu A, et al. 18F-flutemetamol amyloid imaging in Alzheimer disease and mild cognitive impairment: a phase 2 trial. Ann Neurol. 2010; 68(3): 319-329, doi: 10.1002/ ana.22068, indexed in Pubmed: 20687209.

48. Zwan MD, Bouwman FH, Konijnenberg E, et al. Diagnostic impact of [F]flutemetamol PET in early-onset dementia. Alzheimers Res Ther. 2017; 9(1): 2, doi: 10.1186/s13195-016-0228-4, indexed in Pubmed: 28093088.

49. Palmqvist $\mathrm{S}$, Zetterberg $\mathrm{H}$, Mattsson $\mathrm{N}$, et al. Alzheimer's Disease Neuroimaging Initiative, Swedish BioFINDER Study Group. Detailed comparison of amyloid PET and CSF biomarkers for identifying early Alzheimer disease. Neurology. 2015; 85(14): 1240-1249, doi: 10.1212/WNL.0000000000001991, indexed in Pubmed: 26354982.

50. Tomita N, Furukawa K, Okamura N, et al. Brain accumulation of amyloid $\beta$ protein visualized by positron emission tomography and $B F-227$ in Alzheimer's disease patients with or without diabetes mellitus. Geriatr Gerontol Int. 2013; 13(1): 215-221, doi: 10.1111/j.1447-0594.2012.00880.x, indexed in Pubmed: 22680403.

51. Rowe CC, Pejoska S, Mulligan RS, et al. Head-to-head comparison of 11C-PiB and 18F-AZD4694 (NAV4694) for $\beta$-amyloid imaging in aging and dementia. J Nucl Med. 2013; 54(6): 880-886, doi: 10.2967/ jnumed.112.114785, indexed in Pubmed: 23575995.

52. Mohandas E, Rajmohan V. Frontotemporal dementia: An updated overview. Indian J Psychiatry. 2009; 51 Suppl 1: S65-S69, indexed in Pubmed: 21416021.

53. Ishii K, Sakamoto S, Sasaki M, et al. Cerebral glucose metabolism in patients with frontotemporal dementia. J Nucl Med. 1998; 39(11): 1875-1878, indexed in Pubmed: 9829574.

54. Brown RKJ, Bohnen NI, Wong KaK, et al. Brain PET in suspected dementia: patterns of altered FDG metabolism. Radiographics. 2014; 34(3): 684-701, doi: 10.1148/rg.343135065, indexed in Pubmed: 24819789.

55. Mosconi L, Tsui WH, Herholz K, et al. Multicenter standardized 18FFDG PET diagnosis of mild cognitive impairment, Alzheimer's disease, and other dementias. J Nucl Med. 2008; 49(3): 390-398, doi: 10.2967/jnumed.107.045385, indexed in Pubmed: 18287270.

56. Foster NL, Heidebrink JL, Clark CM, et al. FDG-PET improves accuracy in distinguishing frontotemporal dementia and Alzheimer's disease. Brain. 2007; 130(Pt 10): 2616-2635, doi: 10.1093/brain/awm177, indexed in Pubmed: 17704526.

57. Kobylecki C, Langheinrich T, Hinz R, et al. 18F-florbetapir PET in patients with frontotemporal dementia and Alzheimer disease. J Nucl Med. 2015; 56(3): 386-391, doi: 10.2967/jnumed.114.147454, indexed in Pubmed: 25655625.

58. Rabinovici GD, Rosen HJ, Alkalay A, et al. Amyloid vs FDG-PET in the differential diagnosis of AD and FTLD. Neurology. 2011; 77(23): 2034-2042, doi: 10.1212/WNL.0b013e31823b9c5e, indexed in Pubmed: 22131541.

59. Lim SM, Katsifis A, Villemagne VL, et al. The 18F-FDG PET cingulate island sign and comparison to 123I-beta-CIT SPECT for diagnosis of dementia with Lewy bodies. J Nucl Med. 2009; 50(10): 16381645, doi: 10.2967/jnumed.109.065870, indexed in Pubmed: 19759102.

60. Dąbrowska M, Schinwelski M, Sitek EJ, et al. The role of neuroimaging in the diagnosis of the atypical parkinsonian syndromes in clinical practice. Neurol Neurochir Pol. 2015; 49(6): 421-431, doi: 10.1016/j.pjnns.2015.10.002, indexed in Pubmed: 26652877.

61. Villemagne VL, Okamura N, Pejoska S, et al. Differential diagnosis in Alzheimer's disease and dementia with Lewy bodies via VMAT2 and amyloid imaging. Neurodegener Dis. 2012; 10(1-4): 161-165, doi: 10.1159/000334535, indexed in Pubmed: 22261520.

62. Siderowf A, Pontecorvo MJ, Shill HA, et al. PET imaging of amyloid with Florbetapir $F 18$ and PET imaging of dopamine degeneration with 18F-AV-133 (florbenazine) in patients with Alzheimer's disease and Lewy body disorders. BMC Neurol. 2014; 14: 79, doi: 10.1186/14712377-14-79, indexed in Pubmed: 24716655.

63. Johnson KA, Rentz DM, Moran EK, et al. Combined dopamine transporter and FDG PET IN DLB, AD, and PD. Neurobiology of Aging. 2004; 25: S86-S87.

64. Shimada H, Hirano S, Sinotoh H, et al. Dementia with Lewy bodies can be well-differentiated from Alzheimer's disease by measurement of brain acetylcholinesterase activity-a [11C]MP4A PET study. Int J Geriatr Psychiatry. 2015; 30(11): 1105-1113, doi: 10.1002/gps.4338, indexed in Pubmed: 26280153.

65. Kalaria R. Similarities between Alzheimer's disease and vascular dementia. Journal of the Neurological Sciences. 2002; 203-204: 29-34, doi: 10.1016/s0022-510x(02)00256-3.

66. Nobili F, Arbizu J, Bouwman F, et al. EANM-EAN Task Force for the Prescription of FDG-PET for Dementing Neurodegenerative Disorders. European Association of Nuclear Medicine and European Academy of Neurology recommendations for the use of brain F-fluorodeoxyglucose positron emission tomography in neurodegenerative cognitive impairment and dementia: Delphi consensus. Eur J Neurol. 2018; 25(10): 1201-1217, doi: 10.1111/ene.13728, indexed in Pubmed: 29932266.

67. DeCarli C. Mild cognitive impairment: prevalence, prognosis, aetiology, and treatment. Lancet Neurol. 2003; 2(1): 15-21, indexed in Pubmed: 12849297.

68. Mosconi L, Perani D, Sorbi S, et al. MCl conversion to dementia and the APOE genotype: a prediction study with FDG-PET. Neurology. 2004; 63(12): 2332-2340, indexed in Pubmed: 15623696.

69. Anchisi D, Borroni B, Franceschi M, et al. Heterogeneity of brain glucose metabolism in mild cognitive impairment and clinical progression to Alzheimer disease. Arch Neurol. 2005; 62(11): 1728-1733, doi: 10.1001/archneur.62.11.1728, indexed in Pubmed: 16286547.

70. Morbelli S, Piccardo A, Villavecchia G, et al. Mapping brain morphological and functional conversion patterns in amnestic MCl: a voxel-based MRI and FDG-PET study. Eur J Nucl Med Mol Imaging. 2010; 37(1): 36-45, doi: 10.1007/s00259-009-1218-6, indexed in Pubmed: 19662411.

71. Small GW, Mazziotta JC, Collins MT, et al. Apolipoprotein E type 4 allele and cerebral glucose metabolism in relatives at risk for familial Alzheimer disease. JAMA. 1995; 273(12): 942-947, indexed in Pubmed: 7884953.

72. Reiman EM, Caselli RJ, Yun LS, et al. Preclinical evidence of Alzheimer's disease in persons homozygous for the epsilon 4 allele for apolipoprotein E. N Engl J Med. 1996; 334(12): 752-758, doi: 10.1056/ NEJM199603213341202, indexed in Pubmed: 8592548.

73. Yuan Y, Gu ZX, Wei WS. Fluorodeoxyglucose-positron-emission tomography, single-photon emission tomography, and structural MR imaging for prediction of rapid conversion to Alzheimer disease in patients with mild cognitive impairment: a meta-analysis. AJNR Am J Neuroradiol. 2009; 30(2): 404-410, doi: 10.3174/ajnr.A1357, indexed in Pubmed: 19001534. 
74. Kemppainen NM, Scheinin NM, Koivunen J, et al. Five-year follow-up of 11C-PIB uptake in Alzheimer's disease and MCl. Eur J Nucl Med Mol Imaging. 2014; 41(2): 283-289, doi: 10.1007/s00259-0132562-0, indexed in Pubmed: 24072346.

75. Forsberg A, Engler $\mathrm{H}$, Almkvist $\mathrm{O}$, et al. PET imaging of amyloid deposition in patients with mild cognitive impairment. Neurobiol Aging. 2008; 29(10): 1456-1465, doi: 10.1016/j.neurobiolaging.2007.03.029, indexed in Pubmed: 17499392.

76. Koivunen J, Scheinin N, Virta JR, et al. Amyloid PET imaging in patients with mild cognitive impairment: a 2-year follow-up study. Neurology. 2011; 76(12): 1085-1090, doi: 10.1212/WNL.0b013e318212015e, indexed in Pubmed: 21325653.

77. Tolboom N, Yaqub M, van der Flier WM, et al. Detection of Alzheimer pathology in vivo using both 11C-PIB and 18F-FDDNP PET. J Nucl Med. 2009; 50(2): 191-197, doi: 10.2967/jnumed.108.056499, indexed in Pubmed: 19164243.

78. Grimmer T, Wutz C, Alexopoulos P, et al. Visual Versus Fully Automated Analyses of 18F-FDG and Amyloid PET for Prediction of Dementia Due to Alzheimer Disease in Mild Cognitive Impairment. J Nucl Med. 2016; 57(2): 204-207, doi: 10.2967/jnumed.115.163717, indexed in Pubmed: 26585056.

79. Ng S, Villemagne VL, Berlangieri S, et al. Visual assessment versus quantitative assessment of 11C-PIB PET and 18F-FDG PET for detection of Alzheimer's disease. J Nucl Med. 2007; 48(4): 547-552, indexed in Pubmed: 17401090.

80. Prestia A, Caroli A, van der Flier WM, et al. Prediction of dementia in $\mathrm{MCl}$ patients based on core diagnostic markers for Alzheimer disease. Neurology. 2013; 80(11): 1048-1056, doi: 10.1212/ WNL.0b013e3182872830, indexed in Pubmed: 23390179.

81. Scheinin NM, Aalto S, Koikkalainen J, et al. Follow-up of [11C]PIB uptake and brain volume in patients with Alzheimer disease and controls. Neurology. 2009; 73(15): 1186-1192, doi: 10.1212/ WNL.0b013e3181bacf1b, indexed in Pubmed: 19726751.

82. Stefanova E, Wall A, Almkvist $\mathrm{O}$, et al. Longitudinal PET evaluation of cerebral glucose metabolism in rivastigmine treated patients with mild Alzheimer's disease. J Neural Transm (Vienna). 2006; 113(2): 205-218, doi: 10.1007/s00702-005-0312-6, indexed in Pubmed: 16049637.

83. Tune L, Tiseo PJ, leni J, et al. Donepezil HCl (E2020) maintains functional brain activity in patients with Alzheimer disease: results of a 24week, double-blind, placebo-controlled study. Am J Geriatr Psychiatry. 2003; 11(2): 169-177, indexed in Pubmed: 12611746.

84. Slawek J. Parkinson's disease: how to properly diagnose and efectively and safely treat? (Article in Polish). Forum Medycyny Rodzinnej. 2014; 8(6): 281-291.

85. Antony PMA, Diederich NJ, Krüger R, et al. The hallmarks of Parkinson's disease. FEBS J. 2013; 280(23): 5981-5993, doi: 10.1111/ febs.12335, indexed in Pubmed: 23663200.

86. Edison P, Ahmed I, Fan Z, et al. Microglia, amyloid, and glucose metabolism in Parkinson's disease with and without dementia. Neuropsychopharmacology. 2013; 38(6): 938-949, doi: 10.1038/ npp.2012.255, indexed in Pubmed: 23303049.

87. Bohnen NI, Müller ML, Kotagal V, et al. Olfactory dysfunction, central cholinergic integrity and cognitive impairment in Parkinson's disease. Brain. 2010; 133(Pt 6): 1747-1754, doi: 10.1093/brain/awq079, indexed in Pubmed: 20413575.

88. Akdemir ÜÖ, Tokçaer AB, Karakuş A, et al. Brain 18F-FDG PET imaging in the differential diagnosis of parkinsonism. Clin Nucl Med.
2014; 39(3): e220-e226, doi: 10.1097/RLU.0000000000000315, indexed in Pubmed: 24321825.

89. Eckert T, Barnes A, Dhawan V, et al. FDG PET in the differential diagnosis of parkinsonian disorders. Neuroimage. 2005; 26(3): 912-921, doi: 10.1016/j.neuroimage.2005.03.012, indexed in Pubmed: 15955501.

90. Wu P, Wang J, Peng S, et al. Metabolic brain network in the Chinese patients with Parkinson's disease based on 18F-FDG PET imaging. Parkinsonism Relat Disord. 2013; 19(6): 622-627, doi: 10.1016/j. parkreldis.2013.02.013, indexed in Pubmed: 23529021.

91. Pal PK, Wszolek ZK, Uitti R, et al. Positron emission tomography of dopamine pathways in familial Parkinsonian syndromes. Parkinsonism Relat Disord. 2001; 8(1): 51-56, indexed in Pubmed: 11472880.

92. Brooks DJ, Ibanez V, Sawle GV, et al. Differing patterns of striatal 18Fdopa uptake in Parkinson's disease, multiple system atrophy, and progressive supranuclear palsy. Ann Neurol. 1990; 28(4): 547-555, doi: 10.1002/ana.410280412, indexed in Pubmed: 2132742.

93. Gao L, Chen H, Li X, et al. The diagnostic value of minor salivary gland biopsy in clinically diagnosed patients with Parkinson's disease: comparison with DAT PET scans. Neurol Sci. 2015; 36(9): 1575-1580, doi: 10.1007/s10072-015-2190-5, indexed in Pubmed: 25820147.

94. Liu SY, Wu JJ, Zhao J, et al. Onset-related subtypes of Parkinson's disease differ in the patterns of striatal dopaminergic dysfunction: A positron emission tomography study. Parkinsonism Relat Disord. 2015; 21(12): 1448-1453, doi: 10.1016/j.parkreldis.2015.10.017, indexed in Pubmed: 26559130.

95. Chung M, Park YS, Kim JiS, et al. Correlating Parkinson's disease motor symptoms with three-dimensional [(18)F]FP-CIT PET. Jpn J Radiol. 2015; 33(10): 609-618, doi: 10.1007/s11604-015-0427-0, indexed in Pubmed: 25952404.

96. Hsiao IT, Weng YH, Hsieh CJ, et al. Correlation of Parkinson disease severity and 18F-DTBZ positron emission tomography. JAMA Neurol. 2014; 71(6): 758-766, doi: 10.1001/jamaneurol.2014.290, indexed in Pubmed: 24756323.

97. Rinne JO, Laihinen A, Rinne UK, et al. PET study on striatal dopamine D2 receptor changes during the progression of early Parkinson's disease. Mov Disord. 1993; 8(2): 134-138, doi: 10.1002/ mds. 870080203 , indexed in Pubmed: 8474478.

98. Stark AJ, Smith CT, Petersen KJ, et al. [F]fallypride characterization of striatal and extrastriatal $D$ receptors in Parkinson's disease. Neuroimage Clin. 2018; 18: 433-442, doi: 10.1016/j.nicl.2018.02.010, indexed in Pubmed: 29541577.

99. Garcia-Garcia D, Clavero P, Gasca Salas C, et al. Posterior parietooccipital hypometabolism may differentiate mild cognitive impairment from dementia in Parkinson's disease. Eur J Nucl Med Mol Imaging. 2012; 39(11): 1767-1777, doi: 10.1007/s00259-012-2198-5, indexed in Pubmed: 22872307.

100. Hosokai Y, Nishio Y, Hirayama K, et al. Distinct patterns of regional cerebral glucose metabolism in Parkinson's disease with and without mild cognitive impairment. Mov Disord. 2009; 24(6): 854-862, doi: 10.1002/mds.22444, indexed in Pubmed: 19199357.

101. Huang $\mathrm{C}$, Mattis $\mathrm{P}$, Perrine $\mathrm{K}$, et al. Metabolic abnormalities associated with mild cognitive impairment in Parkinson disease. Neurology. 2008; 70(16 Pt 2): 1470-1477, doi: 10.1212/01. wnl.0000304050.05332.9c, indexed in Pubmed: 18367705.

102. Oh YS, Kim JS, Hwang EJ, et al. Striatal dopamine uptake and olfactory dysfunction in patients with early Parkinson's disease. Par- 
kinsonism Relat Disord. 2018; 56: 47-51, doi: 10.1016/j.parkreldis.2018.06.022, indexed in Pubmed: 29925486.

103. Bohnen NI, Gedela S, Herath P, et al. Selective hyposmia in Parkinson disease: association with hippocampal dopamine activity. Neurosci Lett. 2008; 447(1): 12-16, doi: 10.1016/j.neulet.2008.09.070, indexed in Pubmed: 18838108.

104. Hughes AJ, Daniel SE, Ben-Shlomo Y, et al. The accuracy of diagnosis of parkinsonian syndromes in a specialist movement disorder service. Brain. 2002; 125(Pt 4): 861-870, indexed in Pubmed: 11912118.

105. Eggers C, Hilker R, Burghaus L, et al. High resolution positron emission tomography demonstrates basal ganglia dysfunction in early Parkinson's disease. J Neurol Sci. 2009; 276(1-2): 27-30, doi: 10.1016/j.jns.2008.08.029, indexed in Pubmed: 18835490.

106. Schreckenberger M, Hägele S, Siessmeier T, et al. The dopamine D2 receptor ligand 18F-desmethoxyfallypride: an appropriate fluorinated PET tracer for the differential diagnosis of parkinsonism. Eur J Nucl Med Mol Imaging. 2004; 31(8): 1128-1135, doi: 10.1007/s00259004-1465-5, indexed in Pubmed: 15042325.

107. la Fougère $C$, Pöpperl G, Levin J, et al. The value of the dopamine D2/3 receptor ligand 18F-desmethoxyfallypride for the differentiation of idiopathic and nonidiopathic parkinsonian syndromes. J Nucl Med. 2010; 51(4): 581-587, doi: 10.2967/jnumed.109.071811, indexed in Pubmed: 20237026.

108. Zhao P, Zhang B, Gao S. 18[F]-FDG PET study on the Idiopathic Parkinson's disease from several parkinsonian-plus syndromes. Parkinsonism \& Related Disorders. 2012; 18: S60-S62, doi: 10.1016/ s1353-8020(11)70020-7.

109. Taniwaki T, Nakagawa M, Yamada T, et al. Cerebral metabolic changes in early multiple system atrophy: a PET study. J Neurol Sci. 2002; 200(1-2): 79-84, indexed in Pubmed: 12127681.

110. Bu LL, Liu FT, Jiang CF, et al. Patterns of dopamine transporter imaging in subtypes of multiple system atrophy. Acta Neurol Scand. 2018; 138(2): 170-176, doi: 10.1111/ane.12932, indexed in Pubmed: 29573392.

111. Kepe V, Bordelon Y, Boxer A, et al. PET imaging of neuropathology in tauopathies: progressive supranuclear palsy. J Alzheimers Dis. 2013; 36(1): 145-153, doi: 10.3233/JAD-130032, indexed in Pubmed: 23579330.

112. Passamonti L, Vázquez Rodríguez $\mathrm{P}$, Hong YT, et al. 18F-AV-1451 positron emission tomography in Alzheimer's disease and progressive supranuclear palsy. Brain. 2017; 140(3): 781-791, doi: 10.1093/ brain/aww340, indexed in Pubmed: 28122879.

113. Whitwell JL, Lowe VJ, Tosakulwong N, et al. [ F]AV-1451 tau positron emission tomography in progressive supranuclear palsy. Mov Disord. 2017; 32(1): 124-133, doi: 10.1002/mds.26834, indexed in Pubmed: 27787958.

114. Valli M, Strafella AP. New advances in tau imaging in parkinsonism. Int Rev Psychiatry. 2017; 29(6): 628-635, doi: 10.1080/09540261 .2017.1396446, indexed in Pubmed: 29206491.

115. Grijalvo-Perez AM, Litvan I. Corticobasal degeneration. Semin Neurol. 2014; 34(2): 160-173, doi: 10.1055/s-0034-1381734, indexed in Pubmed: 24963675.

116. Niethammer M, Tang CC, Feigin A, et al. A disease-specific metabolic brain network associated with corticobasal degeneration. Brain. 2014; 137(Pt 11): 3036-3046, doi: 10.1093/brain/awu256, indexed in Pubmed: 25208922.

117. Laureys S, Salmon E, Garraux G, et al. Fluorodopa uptake and glucose metabolism in early stages of corticobasal degeneration. J Neurol. 1999; 246(12): 1151-1158, indexed in Pubmed: 10653307.
118. Smith R, Schöll M, Widner H, et al. In vivo retention of F-AV-1451 in corticobasal syndrome. Neurology. 2017; 89(8): 845-853, doi: 10.1212/ WNL.00000000000004264, indexed in Pubmed: 28754841.

119. Kikuchi A, Okamura N, Hasegawa T, et al. In vivo visualization of tau deposits in corticobasal syndrome by $18 \mathrm{~F}-\mathrm{THK} 5351$ PET. Neurology. 2016; 87(22): 2309-2316, doi: 10.1212/ WNL.0000000000003375, indexed in Pubmed: 27794115.

120. Hellwig S, Frings L, Amtage F, et al. 18F-FDG PET Is an Early Predictor of Overall Survival in Suspected Atypical Parkinsonism. J Nucl Med. 2015; 56(10): 1541-1546, doi: 10.2967/jnumed.115.159822, indexed in Pubmed: 26229141.

121. Hellwig S, Amtage F, Kreft A, et al. $\left.{ }^{18} \mathrm{~F}\right]$ FDG-PET is superior to [123|] IBZM-SPECT for the differential diagnosis of parkinsonism. Neurology. 2012; 79(13): 1314-1322, doi: 10.1212/WNL.0b013e31826c1b0a, indexed in Pubmed: 22914831.

122. Fuente-Fernández RD, Lu J, Sossi V, et al. Biochemical variations in the synaptic level of dopamine precede motor fluctuations in Parkinson's disease: PET evidence of increased dopamine turnover. Annals of Neurology. 2001; 49(3): 298-303, doi: 10.1002/ana.65.abs.

123. Chung SuJ, Lee Y, Oh JS, et al. Putaminal dopamine depletion in de novo Parkinson's disease predicts future development of wearingoff. Parkinsonism Relat Disord. 2018; 53: 96-100, doi: 10.1016/j. parkreldis.2018.05.008, indexed in Pubmed: 29776864.

124. Fiszer U. The Current Status of Levodopa Treatment in Parkinson's disease. (Article in Polish). Postępy Nauk Medycznych, t. Postępy Nauk Medycznych. 2012; XXV(1): 2012.

125. Yoo HS, Chung SJ, Chung SuJ, et al. Presynaptic dopamine depletion determines the timing of levodopa-induced dyskinesia onset in Parkinson's disease. Eur J Nucl Med Mol Imaging. 2018; 45(3): 423-431, doi: 10.1007/s00259-017-3844-8, indexed in Pubmed: 29075830.

126. Whone AL, Watts RL, StoessI AJ, et al. REAL-PET Study Group. Slower progression of Parkinson's disease with ropinirole versus levodopa: The REAL-PET study. Ann Neurol. 2003; 54(1): 93-101, doi: 10.1002/ ana.10609, indexed in Pubmed: 12838524.

127. Trost M, Su PC, Barnes A, et al. Evolving metabolic changes during the first postoperative year after subthalamotomy. J Neurosurg. 2003; 99(5): 872-878, doi: 10.3171/jns.2003.99.5.0872, indexed in Pubmed: 14609167.

128. Sauleau P, Le Jeune F, Drapier S, et al. Weight gain following subthalamic nucleus deep brain stimulation: a PET study. Mov Disord. 2014; 29(14): 1781-1787, doi: 10.1002/mds.26063, indexed in Pubmed: 25382049.

129. Axelsen TM, Woldbye DPD. Gene Therapy for Parkinson's Disease, An Update. J Parkinsons Dis. 2018; 8(2): 195-215, doi: 10.3233/ JPD-181331, indexed in Pubmed: 29710735.

130. Yagi S, Yoshikawa E, Futatsubashi M, et al. Progression from unilateral to bilateral parkinsonism in early Parkinson disease: implication of mesocortical dopamine dysfunction by PET. J Nucl Med. 2010; 51(8): 1250-1257, doi: 10.2967/jnumed.110.076802, indexed in Pubmed: 20660377.

131. Heller J, Brcina N, Dogan I, et al. Brain imaging findings in idiopathic REM sleep behavior disorder (RBD) - A systematic review on potential biomarkers for neurodegeneration. Sleep Med Rev. 2017; 34: 23-33, doi: 10.1016/j.smrv.2016.06.006, indexed in Pubmed: 27542516.

132. Holtbernd F, Gagnon JF, Postuma RB, et al. Abnormal metabolic network activity in REM sleep behavior disorder. Neurology. 2014; 82(7): 620-627, doi: 10.1212/WNL.00000000000000130, indexed in Pubmed: 24453082. 
133. Arnaldi D, Morbelli S, Brugnolo A, et al. Functional neuroimaging and clinical features of drug naive patients with de novo Parkinson's disease and probable RBD. Parkinsonism Relat Disord. 2016; 29: 47-53, doi: 10.1016/j.parkreldis.2016.05.031, indexed in Pubmed: 27264343.

134. Arnaldi D, De Carli F, Picco A, et al. Nigro-caudate dopaminergic deafferentation: a marker of REM sleep behavior disorder? Neurobiol Aging. 2015; 36(12): 3300-3305, doi: 10.1016/j.neurobiolaging.2015.08.025, indexed in Pubmed: 26410306.

135. Saberi S, Stauffer JE, Schulte DJ, et al. Neuropathology of Amyotrophic Lateral Sclerosis and Its Variants. Neurol Clin. 2015; 33(4): 855-876, doi: 10.1016/j.ncl.2015.07.012, indexed in Pubmed: 26515626.

136. Cistaro A, Valentini MC, Chiò A, et al. Brain hypermetabolism in amyotrophic lateral sclerosis: a FDG PET study in ALS of spinal and bulbar onset. Eur J Nucl Med Mol Imaging. 2012; 39(2): 251-259, doi: 10.1007/s00259-011-1979-6, indexed in Pubmed: 22089661.

137. Pagani M, Chiò A, Valentini MC, et al. Functional pattern of brain FDG-PET in amyotrophic lateral sclerosis. Neurology. 2014; 83(12): 1067-1074, doi: 10.1212/WNL.0000000000000792, indexed in Pubmed: 25122207.

138. Matías-Guiu JA, Pytel V, Cabrera-Martín MN, et al. Amyloid- and FDGPET imaging in amyotrophic lateral sclerosis. Eur J Nucl Med Mol Imaging. 2016; 43(11): 2050-2060, doi: 10.1007/s00259-0163434-1, indexed in Pubmed: 27262702.

139. Lloyd CM, Richardson MP, Brooks DJ, et al. Extramotor involvement in ALS: PET studies with the GABA(A) ligand [(11)C]flumazenil. Brain. 2000; 123 ( Pt 11): 2289-2296, indexed in Pubmed: 11050028.

140. Turner MR, Hammers A, Al-Chalabi A, et al. Distinct cerebral lesions in sporadic and 'D90A' SOD1 ALS: studies with [11C]flumazenil PET. Brain. 2005; 128(Pt 6): 1323-1329, doi: 10.1093/brain/awh509, indexed in Pubmed: 15843422.
141. Van Laere K, Vanhee A, Verschueren J, et al. Value of 18fluorodeoxyglucose-positron-emission tomography in amyotrophic lateral sclerosis: a prospective study. JAMA Neurol. 2014; 71(5): 553-561, doi: 10.1001/jamaneurol.2014.62, indexed in Pubmed: 24615479.

142. Turner MR, Cagnin A, Turkheimer FE, et al. Evidence of widespread cerebral microglial activation in amyotrophic lateral sclerosis: an [11C] (R)-PK11195 positron emission tomography study. Neurobiol Dis. 2004; 15(3): 601-609, doi: 10.1016/j.nbd.2003.12.012, indexed in Pubmed: 15056468.

143. Zürcher NR, Loggia ML, Lawson R, et al. Increased in vivo glial activation in patients with amyotrophic lateral sclerosis: assessed with [(11)C]-PBR28. Neuroimage Clin. 2015; 7: 409-414, doi: 10.1016/j. nicl.2015.01.009, indexed in Pubmed: 25685708.

144. Johansson A, Engler H, Blomquist G, et al. Evidence for astrocytosis in ALS demonstrated by [11C](L)-deprenyl-D2 PET. J Neurol Sci. 2007; 255(1-2): 17-22, doi: 10.1016/j.jns.2007.01.057, indexed in Pubmed: 17346749.

145. Canosa A, Pagani M, Cistaro A, et al. 18F-FDG-PET correlates of cognitive impairment in ALS. Neurology. 2016; 86(1): 44-49, doi: 10.1212/ WNL.0000000000002242, indexed in Pubmed: 26590270.

146. Jeong Y, Park KC, Cho SS, et al. Pattern of glucose hypometabolism in frontotemporal dementia with motor neuron disease. Neurology. 2005; 64(4): 734-736, doi: 10.1212/01.WNL.0000152047.58767.9D, indexed in Pubmed: 15728305.

147. Turner MR, Hammers A, Al-Chalabi A, et al. Cortical involvement in four cases of primary lateral sclerosis using [(11)C]-flumazenil PET. J Neurol. 2007; 254(8): 1033-1036, doi: 10.1007/s00415-0060482-7, indexed in Pubmed: 17294065.

148. Ikawa M, Okazawa H, Tsujikawa T, et al. Increased oxidative stress is related to disease severity in the ALS motor cortex: A PET study. Neurology. 2015; 84(20): 2033-2039, doi: 10.1212/ WNL.0000000000001588, indexed in Pubmed: 25904686. 